\title{
Investigation of the effect of the brand equity on the repurchase intention by mediation of the brand attractiveness and brand trust
}

\section{Investigación del efecto del valor de la marca en la intención de recompra por mediación del atractivo de la marca y la confiabilidad de la marca}

\author{
HASANI-NASAB, Mahmood $\dagger$ \\ Islamic Azad University, Department of Management, Malayer Branch, Malayer, Iran \\ ID $1^{\text {st }}$ Author: Mahmood, Hasani-Nasab / ORC ID: 0000-0003-4507-4313, Researcher ID Thomson: Q-6779-2118
}

DOI: $10.35429 /$ EJM.2019.23.10.19.33

Received July 24, 2019; Accepted September 10, 2019

\begin{abstract}
The objective of the present research is evaluating the effect of the brand equity on the repurchase intention by mediation of the brand attractiveness and brand trust. The present research is applied and descriptive- survey. The population of this study include 188 staff of Iran insurance company in Hamedan city. The volume of sample considering the Morgan table equals to 127 people. The sampling method is simple random method. Data gathering tool is standard questionnaire. The conformity factor analysis method was used in order to validity examination. The Cronbach's alpha was used for reliability evaluation LIZREL Software was used for date analysis of the structural equations modeling. the obtained results indicated that the brand equity, the brand attractiveness and brand trust have a positive and significant effect on the repurchase intention of Iran insurance company of Hamedan.
\end{abstract}

Brand equity, Repurchase intention, Brand attractiveness, Brand trust

\begin{abstract}
Resumen
El objetivo de la presente investigación es evaluar el efecto del valor de la marca en la intención de recompra mediante la mediación del atractivo y la confianza de la marca. La presente investigación es aplicada y descriptiva-encuesta. La población de este estudio incluye 188 empleados de la compañía de seguros de Irán en la ciudad de Hamedan. El volumen de muestra considerando la tabla Morgan equivale a 127 personas. El método de muestreo es un método aleatorio simple. La herramienta de recopilación de datos es un cuestionario estándar. El método de análisis del factor de conformidad se utilizó para el examen de validez. El alfa de Cronbach se usó para la evaluación de confiabilidad. El software LIZREL se usó para el análisis de fechas del modelado de ecuaciones estructurales. Los resultados obtenidos indicaron que el valor de la marca, el atractivo de la marca y la confianza de la marca tienen un efecto positivo y significativo en la intención de recompra de la compañía de seguros iraní de Hamedan.
\end{abstract}

Valor de marca, Intención de recompra, Atractivo de marca, Confianza de marca

Citation: HASANI-NASAB, Mahmood. Investigation of the effect of the brand equity on the repurchase intention by mediation of the brand attractiveness and brand trust. ECORFAN Journal-Mexico. 2019, 10-23: 19-33.

\footnotetext{
$\dagger$ Researcher contributing first author.
} 


\section{Introduction}

Brand equity is defined as desirability and more value that a brand give to a product compared to a similar product. Some factors such as the perceived quality of brand, the perceived value of brand based on cost, uniqueness of brand tendency to pay more price, awareness of brand name, brand popularity organizational links and stability of brand image are some of dimensions that form the brand equity.

The brand is a relationship tool in the management of relating to the customer and it is valuable from two aspect: first, it decrease the risk for consumer, the second one is that it reduces the decision making cost. Also the brand is one of the effective signals in the market that the company due to information asymmetry use of it.

The information asymmetry can be existing in the services customers. (Sweeney and Swait 2008) and it leads to customer loss. So the company in order to preventing of customer uncertainty satisfies his needs and perform its commitments in front of the customer. If the customers be disappointed of a brand all of the investments and future benefits of the company will be at risk. Thus the brand act as a leverage and encourage the company to act to its commitments. Brand in a long - term relationship leads to commitment between the buyer and the seller.

Therefore brand can be used as a defensive tool of marketing that maintains the present customers and also acts as a aggressive tool that attracts new customers. The importance of the defensive market in the field of services is determined through this knowledge that the cost of attraction of the new customer is very more than maintaining the present customers. Brand is a signal of the product situation. The most important characteristic of a brand as a signal of the product situation is its credibility (Ardem and Swait 2004). The brand equity and its effect on the customers is discussed in the marketing field the performed studies in the service sections indicate that brand dimensions influences on the satisfaction and attitude of the consumer and finally on the repurchase intention in the services section (Samadi, et al. 2009).
Such that a brand with more equity increases the preferences and repurchase intention of the customer (Kim, et al. 2008). what is formed in the mind of the customer with direct(personal usage) and indirect (through advertisement) experience is regarded as the bases of purchase decision (Washbern, et al. 2004). It is a manner that a positive perception of a brand creats a apportunity for the customer that selects a brand among different kinds of a special brand and it encourage buying a brand and its services (Dewoys 2010). The general objective of the present study is investigation and determination of the brand equity on the repurchase intention by mediation of the brand attractiveness and brand trust (case study: Iran insurance company in Hamedan city).

\section{Theoretical literature review}

Brand equity is defined as an increased brand value for company, business and the consumers that brand gives to a product (Farquhar,1989), from late of 1980s after presenting the value based management philosophy the brand equity became a marketing key concepts in the managerial theories and managerial task field.(Srinivasan et, al 2005). The brand is a valuable asset that through time we can see that many investment have been done on it. The movements that showed for the first time the brand equity were two unusual movements. One of them occurred in 1985 and the other occurred in 1987. In 1985, Reckitt Colman payed high cost for Air wick good will of ciba Geigy and this cost is related to some unexplainable cases such as name value and symbol. (Aaker, 1991) This value can be reflexed in customer's attitude, Feeling and action toward a brand and is showed in the prices, market stock and the benefit that a bring for a company. The brand equity is an intangible and very important asset for companies that has financial and psychological value (katler keller 2007).

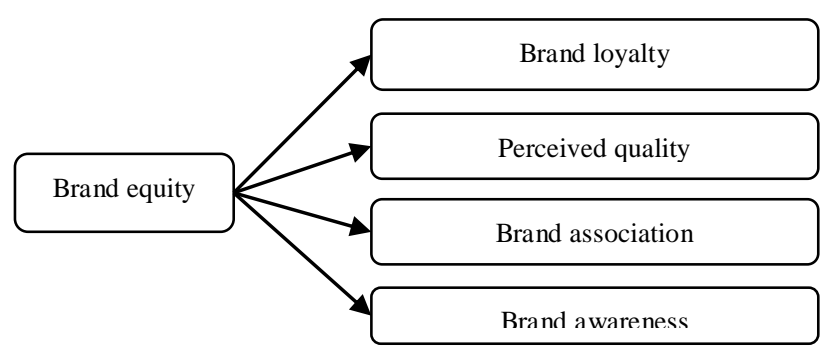

Figure 1 The conceptual model of Aaker brand equity 1996 
Awareness of the brand is the ability of the buyer in distinction and reminding a brand that is placed in a special class of products. It means the informational nodes strength about a brand in individuals mind (Keller, 2008).

Association of the brand is defined as something that guides the brand toward the customers mind. When a brand is stabled in the customers mind creating linkage between associations and the brand will be easier and accordingly the customers can understand the difference between brands and decide to purchase (Aaker, 1991).

The perceived quality is defined as the customer's judgment about preference of the services. Services quality has an abstract and intangible structure from identity point of view and it is not identifiable easity (Bamert,wehrli, kim 2005).

Brand loyalty is defined as customer's attachment to the brand.The strong attachment is the customer's resistance against brand changing and brand sustainability in stormy environments.

Purchase intention: the intention is an important factor in the attitude structure and can predict the actual behavior. when the purchase intention is high the purchase probability will be increased (Kheyvi, Fathali, 2015). Repurchase intention is repetitative purchasing of special goods and services from a shop (Hellier, 2003) and the main reason of it is the experiences after purchasing. the companies can instead of new customers attraction with lower assessment cost maintain their previous customers (Zeithaml, 1996). In the marketing literature there are many studies that mostly have examined the relationship between the repurchase intention and the perceived quality (Alexndris, 2002). In other words the perceived quality has a positive effect on the repurchase intention. In a study that has been done in internet shops and websites kuo stated that the online services quality has a positive correlation with continuous using of web, referring other people and customer loyalty.

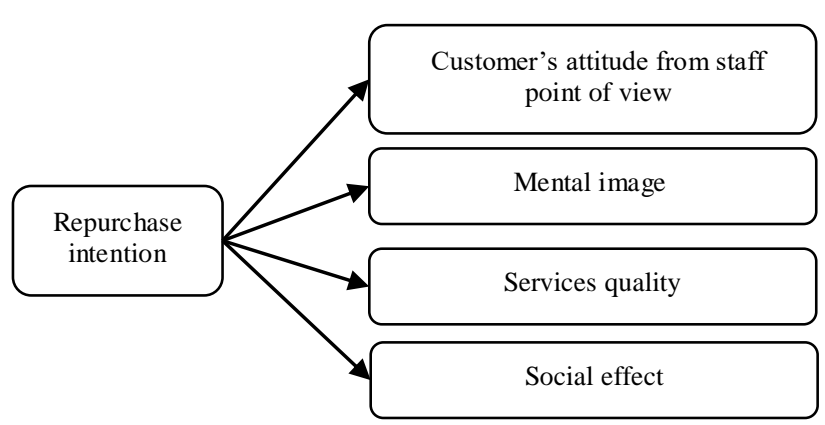

Figure 2 The conceptual model of the repurchase intention khayeri

Source: Fatahli (2015)

The consumers attitude toward the products. The marketing approach for identify the attitudes to the products, brands and services is used to matching the marketing strategies for reflecting the product. Ajzan and Fishbin (1980) stated that the marketer can through creating ideas of the norms and their definition with new concepts that is resulted in evaluations changing has influence on the customer intention (Kheri, Fathali, 1994)

Mental image: An image that a person has of the objective and subjective phenomena is defined as mental image (Kheyri, Fathali, 2015).

Perception of the shop brand: The perception is a canal and viewpoint that we can observe and understand the external world. The perception is more complex than feeling. The conceptual process includes the effect of selection and organizing and interpreting:

1. The factors of the characteristic of the preceptor such as attitudes, expectances interests,experiences and personality (internal factors).

2. The factors that are related to the subject, situation, purpose and context (external factors).

Social effect: Awareness from this subject that the consumer status is depended on other people presence can effect on the consumers performance. The social effect on purchase intention of merchandises and services has been discussed and supported by many of researchers in an experimental method. The consumers that is adaptable socially are excited for obtaining a product for showing their social situation and obtaining social groups. 
Self - conceit: Is defined as over pride (physical self-conceit) or performance (the pride as a result of success). Mir, et al, in 1995 divided the self - conceit in to four categories:

\section{Physical attachment \\ 2. Physical viewpoint \\ 3. Attachment to success \\ 4. Success viewpoint}

The first case means that the individual care his physical appearance. The physical viewpoint means that the individual has a positive (perhaps false) to his physical appearance. Attachment to the success means having a positive understanding of success. In addition the individual believes that other people wish his success. The success viewpoint means that an individual has a positive viewpoint of his success (perhaps false) (Kheyri, Fathali, 2015).

Services quality is one of the most important factors for the next reference of the customer. The managers are successful that can guarantee the quality for the customers.

It is possible that the customers can bear bad treatment, time wasting and promise breach but it is expected from you to present high quality services.

Brand attraction is defined as existing a randomly, long-term behavioral response as a result of psychological process of purchasing a brand, that is performed by a person among other brands (Crosno, et al, 2009).

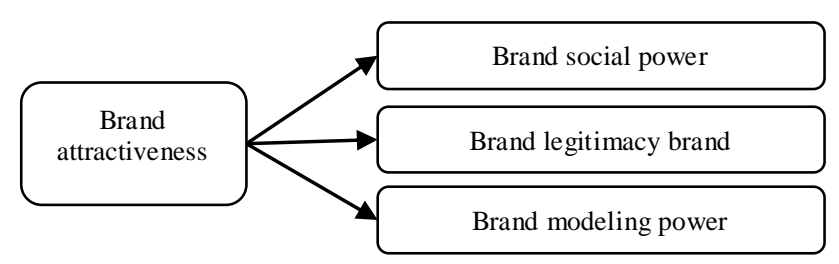

Figure 3 The conceptual model of the brand attractiveness of crosno, et al (2009)

Brand social power: brand forcible social power emphasis on the brand ability in effecting on the consumer behavior through creating awareness of the negative consequences (such as dissatisfaction, rejection or unacceptance feeling, lower conceptual social situation,etc.) if the considered brand is not used.
Brand legitimate power: brand legitimate social power emphasis on the brand ability in effecting on the consumer,behavior through market stock, reputation and oldness in the related industry.

Brand modeling power: brand modeling social power emphasis on the brand ability in effecting on the consumer's behavior with strengthening the attraction or feeling create relationship to brand due to its uniqueness. When a brand has high modeling social power the consumers of a brand has uniqueness feeling and try to near to it.

Brand trust: brand trust is defined as believing this fact that other people will behave in a manner that is in favor of for the company with a special brand, or at least is not injurious for it (Gambeta, 1981). The trust in different areas such as psychology,sociology, economics and also its applied areas such as the management and marketing have attracted the researchers attention. this interest in different fields has resulted in increasing structural power, but it also have difficulted the unify of different viewpoints in trust and consensus field in its identity field. Thas the literature review indicates that the expectance of the confidence and risk are crucial components of trust definition. Accordingly the trust is defined as a confidence that a person distincts to a state that there is not any confidence (Etemadifard,et al, 2013). This subject shows the confidence that a person can not use it by victization of other person. Accordingly trusting to a brand indicates that there is high expectance or probability that a brand leads to positive results for consumer. Hiscock (2001) believed that the final purpose of the marketing is creating a strong tie between the consumer and the brand trust.

Upamannyn (2014) considering the brand trust as expectance it should be said that this fact is based on this believe of the consumer that the related brand has special qualities that leads to stability,competence, truth, responsibility, etc. and is concordant with the research about trust. considering the research of brand trust of Delgado,et al(2003) is seen that these special properties have technical identity that is according to two dimensional idea of trust that is found in managerial and marketing sources. 
As a result the first dimension of brand trust (validity) has technical or competence identity that effects on the ability and tendency to guarantee and satisfying the customer's needs. The second dimension (intention) is formed of good will to brand in relation to the consumer interests and welfare.

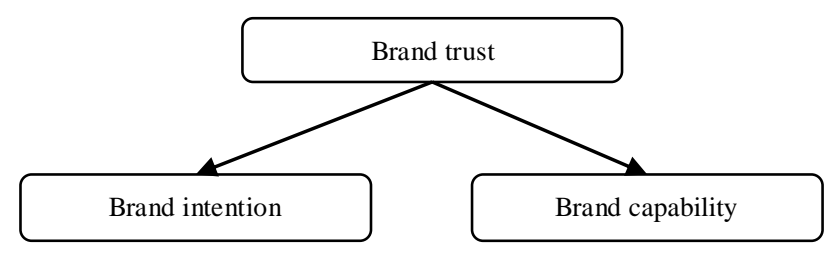

Figure 4 The conceptual model of brand trust of Bulster (2004)

Literature review: Qolipour, et al. (2015) performed a research under the title of the brand equity on the repurchase intention by mediation of the perceived value. The research results indicate that the brand equity effects on the perceived value and repurchase intention and also the perceived value has a positive and significant effect on the repurchase intention of the life policyholders. The brand awareness and brand association have not a significant effect on the perceived value and repurchase intention, the perceived quality in an indirect manner though the perceived value has a positive and significant effect on the repurchase intention and finally the brand loyalty is the only dimension that has a positive and significant effect directly and indirectly on the repurchase intention of life policyholder through the perceived value.

Danayi torabi, Talesh (2014) performed a study under the title of the investigation of the relationship between the brand equity and life insurance policyholders and the repurchase intention. the obtained results indicated that the brand equity has positive effect on the perceived value and repurchase intention and also the perceived value has appositive effect on the repurchase intention of Asia insurance life insurance policyholders the brand association, the perceived quality and the brand loyalty have a positive and significant effect on the two variables of the perceived value and repurchase intention and finally some recommendations were presented separately for each hypothesis.
Marjani et al (2014) performed a study under the title of the effectiveness of the advertisement on the brand equity in tire industry. These stated that the effectiveness of advertisements is one of the most important issues in the advertisement area.

Seyedin (2012) in his research under the title of the investigation of the relationship between the brand equity and the insurance companies performance in life insurance sale state that the brand equity is one of the concepts that distinct the brand from each other. What attracts the consumer toward a brand and leads to its selection is its value the is identified as brand equity.

Dehdashti, et al (2010) in their study under the title of a model examination of the effect of the trust ability of banks state that increase in competition in services section leads to more attention to maintaining the present customers and effort to attracting new customers.

Hossein. et al (2009) in their investigation under the title of the investigation of the effect of brand equity on the consumers response state that one of the most valuable assets of a company is its brand.

Sahin. et al (2013) performed a study under the title of creating commitment, trust relationship and satisfaction for a brand: What is the role of transfer cost in mobile market this research present some reasonable evidences for the future studies by obtaining more attitude toward transfer cost,satisfaction, trust and commitment of a brand and include several concepts for managerial measures and future researches. Transfer cost have a positive effect on the relationship between the trust, satisfaction and the commitment of the brand. This empirical research presents a new method for understanding the effects of the transfer cost on the relationships between satisfaction, trust and commitment of a brand.

Perepelkin and Dizhang (2011) in their study under the title of brand personality and customers trust in pharmacies obtained this result that there is a significant difference from brand personality point of view between different kinds of the pharmacies. 
In other words the consumers have ranked the independent pharmacies to some extent more trustable than multinational merchandises and national chain pharmacies they also concluded that the truth and competence have the most significant effect on the customers trust attraction. They found that the organizations with creating brand personality that has truth and competence can distinct themselves from other organizations that leads to customers trust attraction.

They also have found that the organizations should try to cruet brand personality that is coordinate with the company purposes in best form.

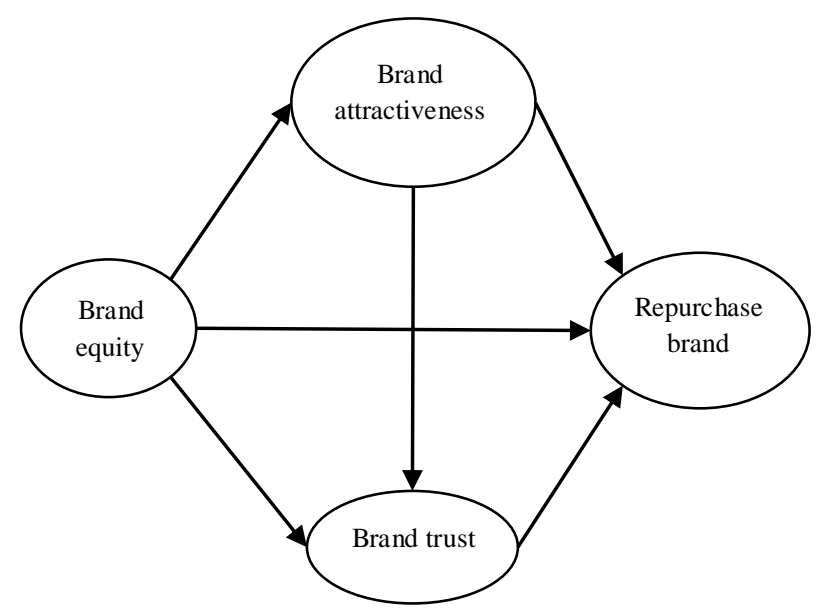

Figure 5 Research operational model

\section{Research hypothesis of the research}

The brand equity has a positive and significant effect on the repurchase intention with mediation of brand attractiveness and brand trust of Iran insurance company in Hamedan.

1. The brand equity has a positive and significant effect on the repurchase intention in Iran insurance company in Hamedan city.

2. The brand equity has a positive and significant effect on the brand attractiveness in Iran insurance company in Hamedan.

3. The brand equity has a positive and significant effect on the brand trust in Iran insurance company in Hamedan city.
4. The brand attractiveness has positive and significant effect on the repurchase intention of Iran insurance company in Hamedan city.

5. The brand trust has a positive and significant effect on the repurchase intention in Iran insurance company in Hamedan city.

6. The brand attractiveness has a positive and significant effect on the brand trust in Iran insurance company in Hamedan.

\section{Research methodology}

The present research is an applied study from purpose point of view and is a descriptive survey from data gathering point of view. The population of this study includes 188 staff of Iran insurance company in Hamedan city and they also are regarded as the customers of this company.

The sample volume of this research estimated as 127 people according to the Morgan table. The simple - random method was used for sampling. The standard questionnaire was used as data gathering tool. the conformational factor analysis method was used for validity examination that its results indicated that the factor analysis is suitable for identifying the factor model structure. The Cronbach's alpha was used for reliability analysis that is more than $0 / 7$ for each one of the research questionnaire components. The structural equations modeling was used for data analysis by LIZREL software.

In order to validity examination the conformational factor analysis test was used. In doing the factor analysis of this issue should be assured that whether. The existing data can be used for data analysis or not?

In other words whether the number of the considered data for factor analysis is suitable or not? At this regard the KMO index and Bartlett test were used.

According to these tests the data are suitable for factor analysis if the KMO index is more than (0/6) and near to and Bartlett test sig is less than $(0 / 05)$ 
The output of this examination is presented in the following.

\begin{tabular}{|c|c|c|}
\hline 0.803 & & Test KMO \\
\hline 540.542 & Chi-squre & \multirow{3}{*}{ Bartlet test } \\
\hline 91 & $\begin{array}{l}\text { Freeedom } \\
\text { degree }\end{array}$ & \\
\hline 0.000 & (sig) & \\
\hline
\end{tabular}

Table 1 The results of KMO test and Bartlett test

Considering table 1 , the KMO index rate is equal to $0 / 803$ and is more than $0 / 6$ rate, thus the sample number (the number of respondents is sufficient for factor analysis. Also Bartlett test sig is less than 0/05 that indicates that the factor analysis is suitable for factor model structure and the assumption of being recognized of the correlation matrix is rejected. All of four questionnaires have validity. The researcher choose the Cronbach's alpha method among the reliability determination methods because the alpha coefficient for all of the four questionnaires is more than $0 / 7$, it has an acceptable reliability (Momeni and Faal Qayoomi 2010, 2012).

\section{Research results}

The descriptive statistics show that the age mean of the respondents is equal to 34/29, 104 people $(81 / 9 \%)$ of the respondents were male and 23 respondents were female. (18/1\%). Educational level of them were as follows 6 of them had diploma $(4 / 7 \%)$. 17 had an undergraduate degree $(13 / 4 \%)$, had bachelor's degree $(54 / 3 \%)$ and finally 35 were masters and higher $(27 / 6)$.

In the inferential statistics at first the normality of the research variables distribution was examined. Accordingly in the present study the Kolmogorov - Smirnov was used for examination of the research data normality assumption. In this examination the significance level for all of the variables is more than test level $(0 / 05)$, thus data distribution is normal and the parametric tests can be used. In this section by means of the structural equation modeling method we will evaluate the research hypotheses. The basis of analysis in the structural equation is the existing correlations between the research variables. Table 2 shows the correlation between the research variables and their significance level.
The correlation snows the relationship kind and the direction of the relationship between two variables. And this fact that this increasing or reducing have what effect on the other variable increasing or decreasing. But this correlation does not mean that there is not a causal relationship between variables. The following table shows the correlation between the research variables and their significance level:

\begin{tabular}{|l|l|l|l|l|}
\hline (4) & \multicolumn{1}{|c|}{ (3) } & \multicolumn{1}{|c|}{ (1) } & \multicolumn{1}{|c|}{ Variable } \\
\hline & & 1 & 1 & Brand equity \\
\hline & 1 & $0.571 * *$ & $0.655^{* *}$ & $\begin{array}{l}\text { Brand } \\
\text { attractiveness }\end{array}$ \\
\hline 1 & $0.721 * *$ & $0.642 * *$ & $0.670 * *$ & $\begin{array}{l}\text { Brand trust } \\
\text { Repurchase } \\
\text { intention }\end{array}$ \\
\hline
\end{tabular}

Correlation in the level of 70/05

Significant correlation**

Table 2 The internal correlation of the variables

\section{The first hypothesis test}

The brand equity has a positive and significant effect on the repurchase intention in Iran insurance company in Hamedan city.

Graphs 1 and 2 show the research models in estimation and significance state of the factor loads and path coefficients. Considering these models we can estimate the factor loads and then test them. The existing coefficients in these graphs are divided in to two categories. The first category includes the relationships between the hidden variables (elliptical) and obvious variables (rectangular) that they are called factor loaded the second category include the relationships between the hidden variable and they are hidden that are called the structural equations and are used for thy hypotheses testing. All of the path coefficients are tested by means of $\mathrm{T}$ statistics.

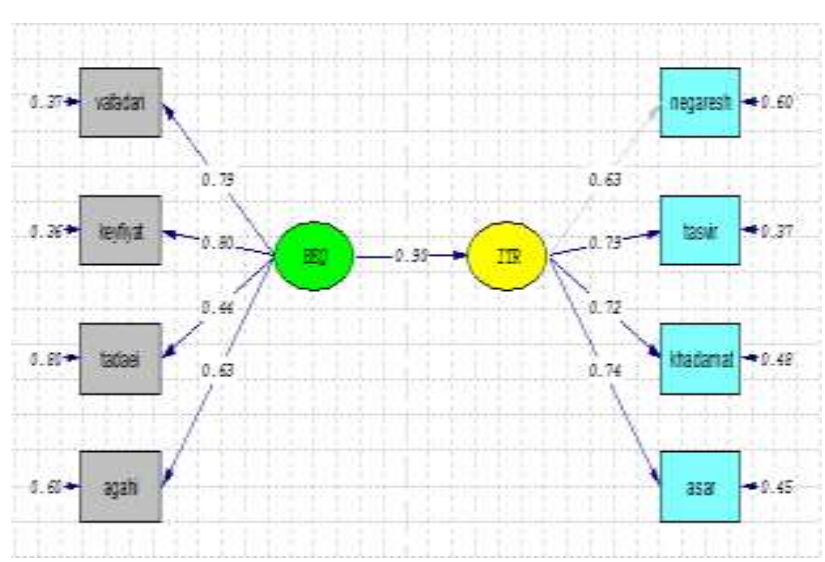

Graph 1 The research model in estimation state with the standard coefficients of the first hypothesis

HASANI-NASAB, Mahmood. Investigation of the effect of the brand equity on the repurchase intention by mediation of the brand attractiveness and brand trust. ECORFAN Journal-Mexico. 2019. 


\begin{tabular}{|l|l|l|l|l|lr|l|}
\hline CFI & NFI & AGFI & GFI & RMSEA & $x^{2} / d f$ & FD & $\begin{array}{l}\text { Chi- } \\
\text { squre }\end{array}$ \\
\hline $0 / 1$ & $0 / 97$ & $0 / 92$ & $0 / 96$ & $0 / 039$ & $2 / 18$ & 19 & $22 / 72$ \\
\hline
\end{tabular}

Table 3 The summary of the goodness of fit for the conceptual model of the first hypothesis

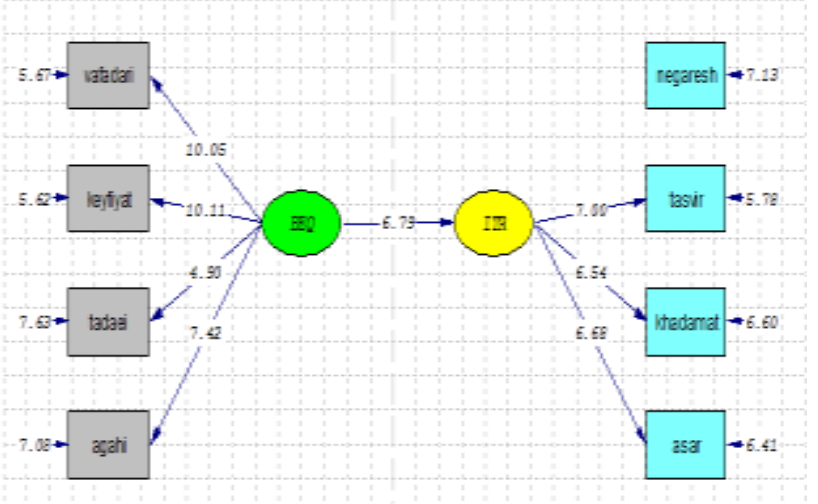

Graph 2 The research model in the significance state (t rates) of the first hypothesis

\begin{tabular}{|l|l|l|l|}
\hline Result & -Statistic t & $\begin{array}{l}\text { Path coefficient } \\
(ß)\end{array}$ & $\begin{array}{l}\text { The first } \\
\text { hypothesis }\end{array}$ \\
\hline Confirmed & 6.79 & 0.9 & \\
\hline
\end{tabular}

Table 4 The results of the examination of the first hypothesis of the research

\section{The second hypothesis test}

The brand equity has a positive and significant effect on the brand attractiveness of Iran insurance company in Hamedan city.

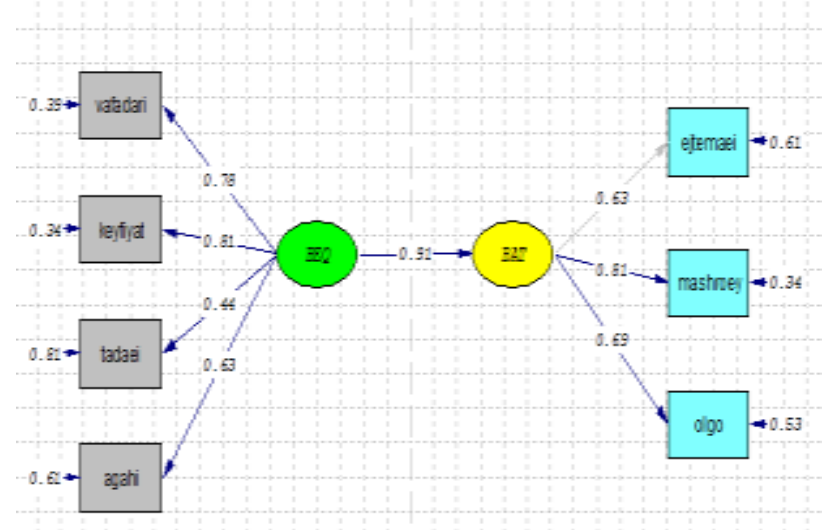

Graph 3 The research model in estimation state with the standard coefficients of the second hypothesis

\begin{tabular}{|l|l|l|l|l|l|l|l|}
\hline \multicolumn{1}{|l|}{ CFI } & NFI & AGFI & GFI & RMSEA & $x^{2} / d f$ & FD & $\begin{array}{l}\text { Chi- } \\
\text { squre }\end{array}$ \\
\hline $0 / 1$ & $0 / 97$ & $0 / 93$ & $0 / 97$ & $0 / 04$ & $2 / 22$ & 13 & $15 / 62$ \\
\hline
\end{tabular}

Table 5 The summary of the goodness of fit for the conceptual model of the second hypothesis

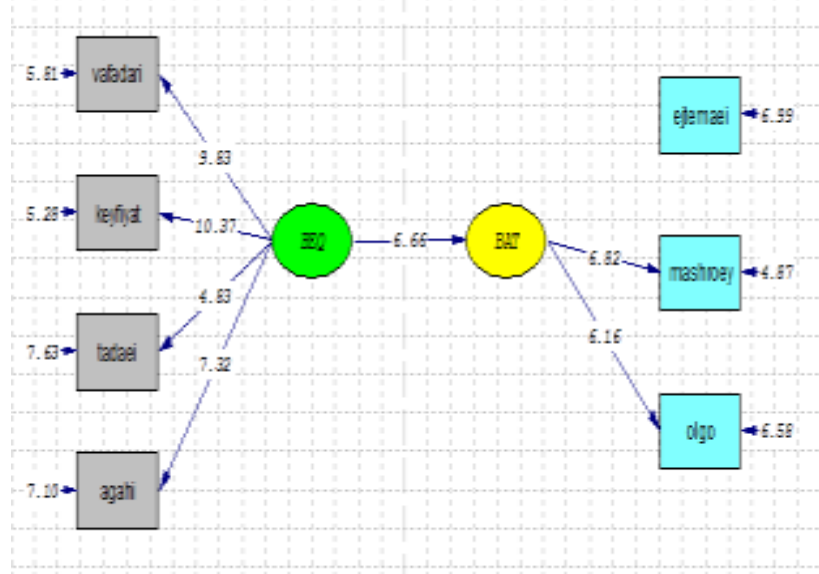

Graph 4 The research model in the significance state (tvates) of the second hypothesis

\begin{tabular}{|l|l|l|l|}
\hline Result & -Statistic t & $\begin{array}{l}\text { Path } \\
\text { coefficient(ß) }\end{array}$ & $\begin{array}{l}\text { The second } \\
\text { hypothesis }\end{array}$ \\
\hline Confirmed & 6.66 & 0.91 & \\
\hline
\end{tabular}

Table 6 The results of the examination of the second hypothesis of the research

\section{The third hypothesis test}

The brand equity has appositive and significant effect an the brand trust in Iran insurance company in Hamedan city.

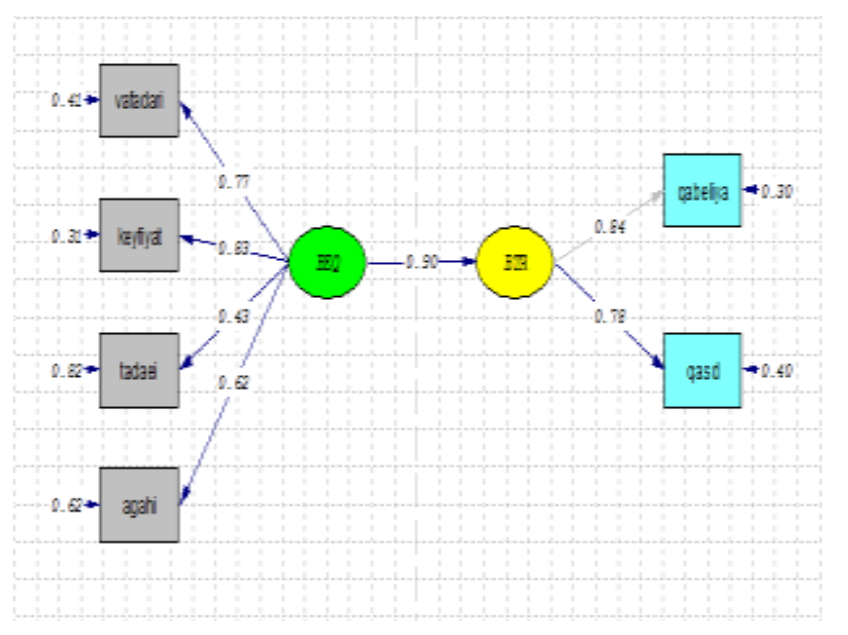

Graph 5 The research model in the estimation state with standard coefficients of the third hypothesis

\begin{tabular}{|l|l|l|l|l|l|l|l|}
\hline CFI & NFI & AGFI & GFI & RMSEA $\mid$ & $x^{2} / d f$ & FD & $\begin{array}{l}\text { Chi- } \\
\text { squre }\end{array}$ \\
\hline $0 / 99$ & $0 / 98$ & $0 / 92$ & $0 / 97$ & $0 / 058$ & $2 / 26$ & 8 & $11 / 42$ \\
\hline
\end{tabular}

Table 7 The summary of the goodness of fit for the conceptual model of the third hypothesis 


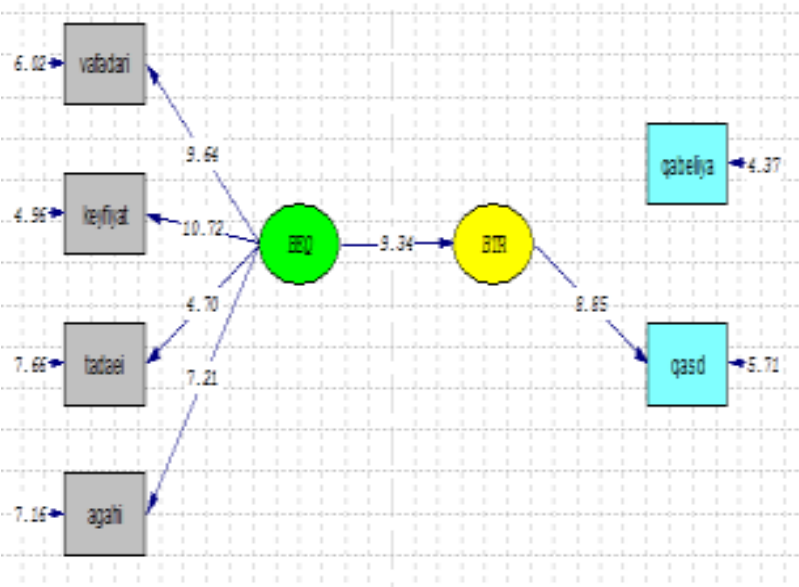

Graph 6 The research model in the significance state $(\mathrm{t}-$ rates) of the third hypothesis

\begin{tabular}{|l|l|l|l|}
\hline Result & -Statistic $\mathrm{t}$ & $\begin{array}{l}\text { Path } \\
\text { coefficient(}(\mathbb{})\end{array}$ & $\begin{array}{l}\text { The third } \\
\text { hypothesis }\end{array}$ \\
\hline Confirmed & 9.34 & 0.90 & \\
\hline
\end{tabular}

Table 8 The results of the examination of the third hypothesis of the research

\section{The fourth hypothesis test}

The brand attractiveness has a positive and significant effect on therepurchase intention in Iran insurance company in Hamedan city.

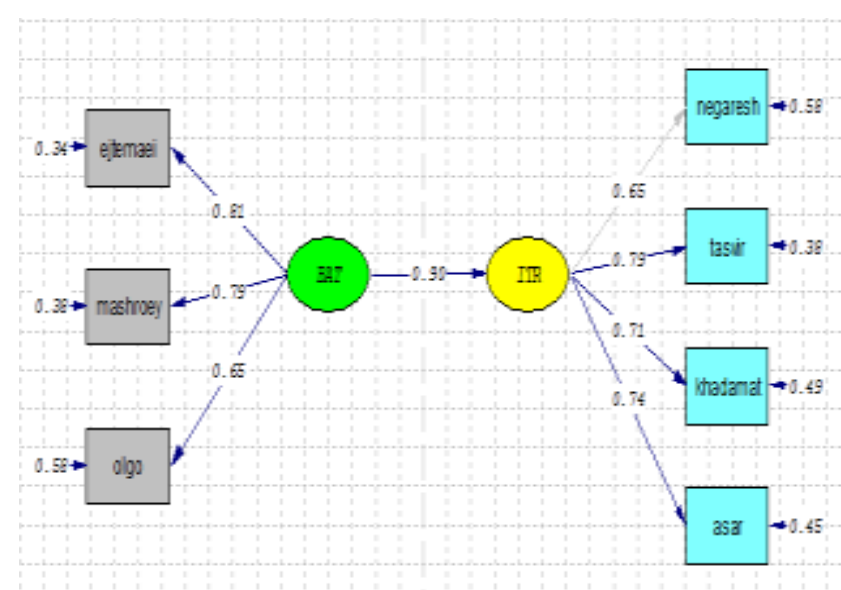

Graph 7 The research model in the estimation state with standard coefficient of the fourth hypothesis

\begin{tabular}{|l|l|l|c|lcc|l|}
\hline CFI & NFI & AGFI & GFI & RMSEA & $x^{2} / d f$ & FD & $\begin{array}{l}\text { Chi- } \\
\text { squre }\end{array}$ \\
\hline $0 / 98$ & $0 / 97$ & $0 / 89$ & $0 / 95$ & $0 / 079$ & $2 / 35$ & 13 & $23 / 10$ \\
\hline
\end{tabular}

Table 9 The summary of the goodness of fit for the conceptual model of the fourth hypothesis

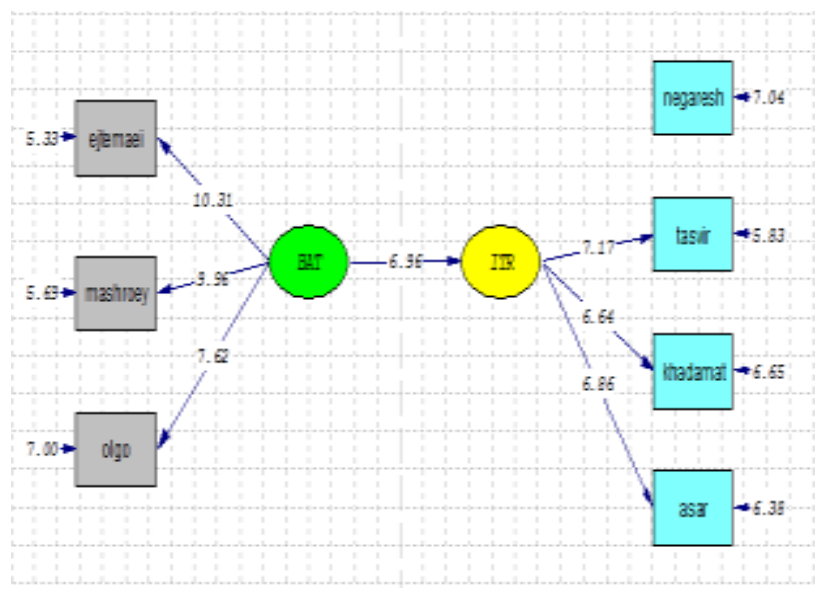

Graph 8 The research model in the significance state ( $\mathrm{t}$ rates) of the fourth hypothesis

\begin{tabular}{|l|l|l|l|}
\hline Result & -Statistic t & $\begin{array}{l}\text { Path } \\
\text { coefficient(ß) }\end{array}$ & $\begin{array}{l}\text { The fourth } \\
\text { hypothesis }\end{array}$ \\
\hline Confirmed & 6.96 & 0.90 & \\
\hline
\end{tabular}

Table 10 The results of the examination of the fourth hypothesis of the research

\section{The fifth hypothesis test}

The brand equity has a positive and significant effect on the repurchase intention in Iran insurance company in Hamedan.

\begin{tabular}{|l|l|l|l|l|l|l|l|}
\hline CFI & NFI & AGFI & GFI & RMSEA & $x^{2} / d f$ & FD & $\begin{array}{l}\text { Chi- } \\
\text { squre }\end{array}$ \\
\hline $0 / 98$ & $0 / 96$ & $0 / 91$ & $0 / 97$ & $0 / 073$ & $2 / 48$ & 8 & $13 / 37$ \\
\hline
\end{tabular}

Table 11 The summary of the goodness of fit for the conceptual model of the fifth hypothesis

\begin{tabular}{|l|ll|l|}
\hline Result & -Statistic t & $\begin{array}{l}\text { Path } \\
\text { coefficient(ß) }\end{array}$ & $\begin{array}{l}\text { The fifth } \\
\text { hypothesis }\end{array}$ \\
\hline Confirmed & 5.17 & 0.80 & \\
\hline
\end{tabular}

Table 12 The results of the examination of the fifth hypothesis of the research

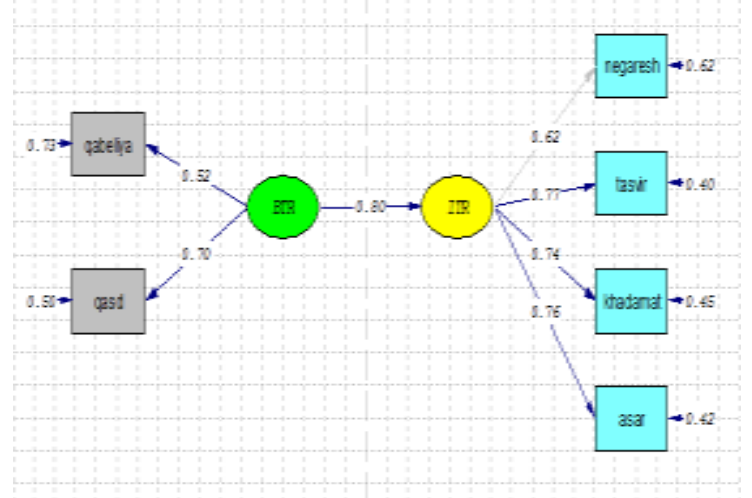

Graph 9 The research model in the estimation state with standard coefficient of the fifth hypothesis 


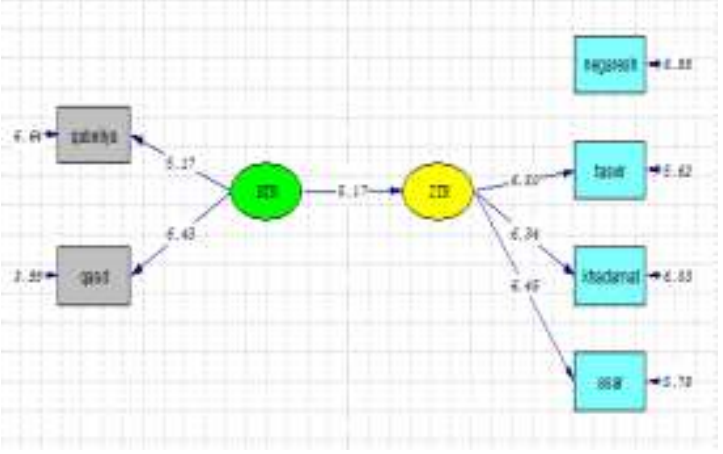

Graph 10 The research model in the significance state (trates) of the fifth hypothesis

\section{The sixth hypothesis test}

The brand attractiveness has a significant and positive effect on the brand trust in Iran insurance company in Hamedan.

\begin{tabular}{|c|c|c|c|c|c|c|c|}
\hline CFI & NFI & AGFI & GFI & RMSEA & $x^{2} / d f$ & FD & $\begin{array}{l}\text { Chi- } \\
\text { squre }\end{array}$ \\
\hline $0 / 1$ & $0 / 99$ & $0 / 97$ & $0 / 99$ & $0 / 000$ & $2 / 52$ & 4 & $2 / 31$ \\
\hline
\end{tabular}

Table 13 The summary of the goodness of fit for the conceptual model of the sixth hypothesis

\begin{tabular}{|ll|l|l|}
\hline Result & -Statistic $\mathrm{t}$ & $\begin{array}{l}\text { Path coefficient } \\
(ß)\end{array}$ & $\begin{array}{l}\text { The fifth } \\
\text { hypothesis }\end{array}$ \\
\hline Confirmed & 7.63 & 0.90 & \\
\hline
\end{tabular}

Table 14 The results of the examination of the sixth hypothesis of the research

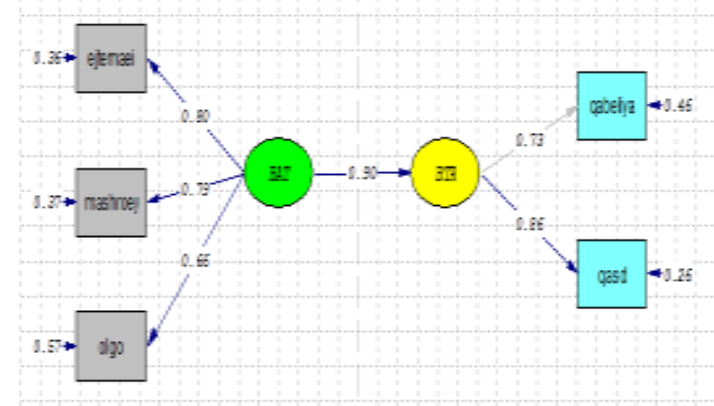

Graph 11 The research model in the estiuation state with standard coefficients of the sixth hypothesis

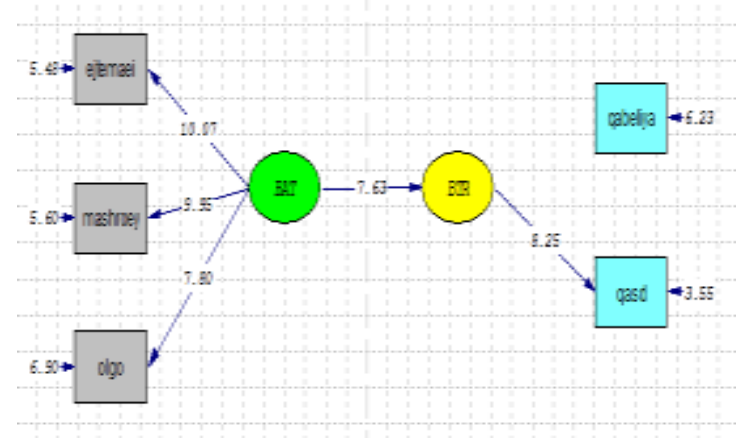

Graph 12 The research model in the significance state (trates) of the sixth hypothesis

\section{The general hypothesis test}

The brand equity has appositive and significant effect on the repurchase intention with the mediation of the brand attractiveness and brand trust of the Iran insurance company in Hamedan city.

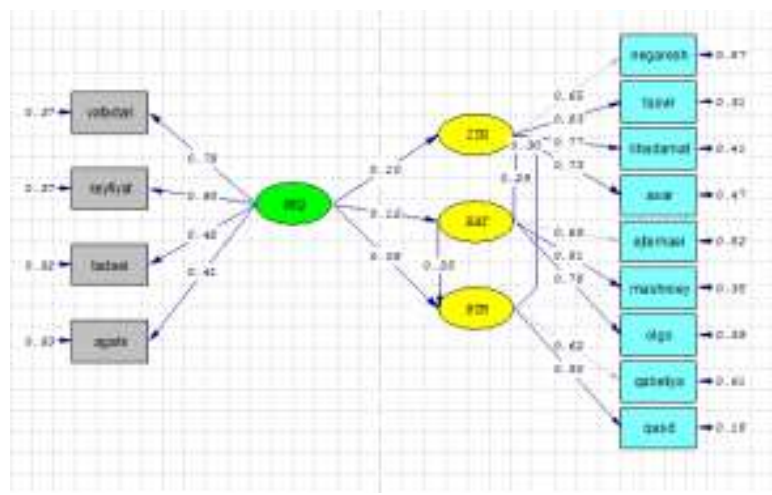

Graph 13 The research model in the estimation state with standard coefficients

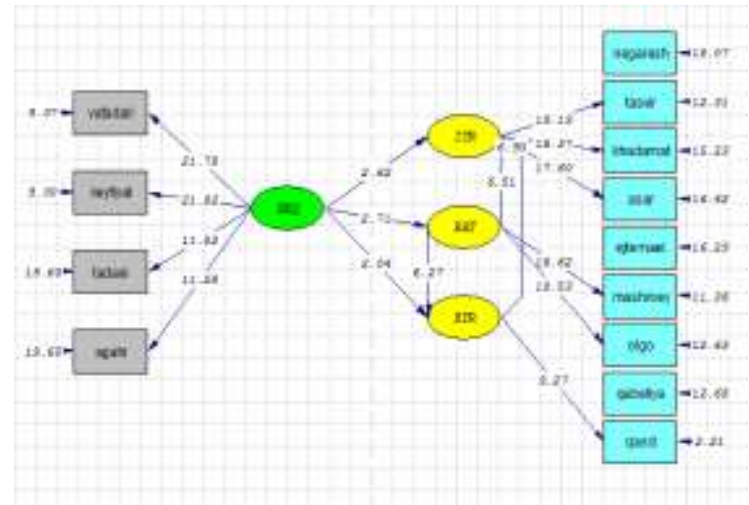

Graph 14 The research model in the significance state (trates)

\begin{tabular}{|l|l|l|l|l|l|l|l|}
\hline CFI & NFI & AGFI & GFI & RMSEA $\mid$ & $x^{2} / d f$ & FD & $\begin{array}{l}\text { Chi- } \\
\text { squre }\end{array}$ \\
\hline 0.88 & 0.87 & 0.84 & 0.90 & 0.11 & 2.81 & 59 & 635.36 \\
\hline
\end{tabular}

Table 15 The summary of the goodness of of the final model

Considering the obtained results of the examination of this hypothesis it can be said that the brand equity has a positive and significant effect on the repurchase intention. With mediation of brand attractiveness and brand trust in Iran insurance company in Hamedan city.

\section{Conclusion and discussion}

The obtained results of the first hypothesis analysis indicated that the brand equity has a positive and significant effect on the repurchase intention in Iran insurance company in Hamedan city.

HASANI-NASAB, Mahmood. Investigation of the effect of the brand equity on the repurchase intention by mediation of the brand attractiveness and brand trust. ECORFAN Journal-Mexico. 2019. 
According to the results of model calculations the value of chi - square goodness of fit index of $35 / 32 x^{2}$ with degree of freedom 19 and significance level of $\mathrm{p}=0 / 0127$ was obtained.

Other attributes of model fitness include the root index of the mean error of approximate squares $(\mathrm{RMSEA}=0 / 039)$, the goodness of fit index (GFI $=0 / 92)$, the modified goodness of fit index $(\mathrm{AGFI}=0 / 92)$ the normed index of the fitness $(\mathrm{NFI}=0 / 97)$ and adaptive fitness index $(\mathrm{CFI}=0 / 01)$ that indicate that models fitness is suitable.

The obtained results indicate that considering the path coefficient (0/9) it is certain that the effect of brand equity on the repurchase intention in Iran insurance company is positive and Ho is rejected And its opposite hypothesis $\mathrm{H} 1$ is confirmed.

The value of $t$ - statistic between the variables of brand equity and repurchase intention is equal to $6 / 79$ that is more than $1 / 96$ and it indicates that the relationship between the brand equity and the repurchase intention in confidence level of $95 \%$ is significant. thus, it can be said that considering this fact that the $t-$ statistics rate of the first hypothesis $(6 / 79)$ is out of the range of $-1 / 96$ and $+1 / 96$, therefore the first hypothesis is confirmed. In other words it can be said that the brand equity can justify $90 \%$ of the changes in the repurchase intention.

Therefore, the first hypothesis is confirmed. In other words it can be said that the brand equity has a positive and significant effect on the repurchase intention in Iran insurance company in Hamedan city. Therefore any evidence for rejection of the first hypothesis was not observed and this hypothesis cannot be rejected.

The obtained results of the second hypothesis indicated that the brand equity has a positive and significant effect on the brand attractiveness in Iran insurance company in Hamedan city. According to the calculated results of the model the value of the chi-squad goodness of fit index of $15 / 62 x^{2}$ with degree of freedom 13 and signifance level of $p=0 / 33$ was obtained.
Other attributes of model fitness include the root index of the mean error of approximate squares $(\mathrm{RMSE}=0 / 04)$, the modified goodness of fit index (AGFI =0/93), the normed index of the fitness (NFI $=0 / 97)$ and adaptive fitness index $(\mathrm{GFI}=0 / 1)$ that indicated that the models fitness is suitable. The obtained results indicate that considering the path coefficient $(0 / 91)$ it is certain that the effect of brand equity on the brand attractiveness in Iran insurance company is positive and $\mathrm{Ho}$ is rejected and its opposite hypothesis is confirmed. the value of $\mathrm{t}-$ statics between the variable of the brand equity and the brand attractiveness is equal to $6 / 60$ that is more than $1 / 96$ and it indicates that the relationship between the brand equity and brand attractiveness in the confidence level of $95 \%$ is significant thus it can be said that the t-statistics rate of the second hypothesis $(6 / 66)$ is out of the range of $1 / 96$ to $+1 / 96$, these the second hypothesis is confirmed, In other words it can be said that the brand equity can justify $91 \%$ of changes in brand attractiveness. Therefore the is confirmed. In the other words it can be said that the brand equity has a positive and significant effect on the brand attractiveness in Iran insurance company in Hamedan city. Therefore, can evidence for rejection of the second hypothesis was not observed and this hypothesis cannot be rejected.

The obtained results of the third hypothesis of the hypothesis indicated that the brand equity has a positive and significant effect on the brand trust in Iran insurance company in Hamedan. According to the results of model calculations the value of chi-square goodness of fit index of 11/42 $x^{2}$ with degree of freedom 8 and significance level of $p=0 / 22$ were obtained. other attributes of the model fitness include the root index of the mean error of approximate squares (RMSEA $=0 / 058)$, the goodness of it index $(\mathrm{GFI}=0 / 98)$ and the modified goodness index $($ AGFI $=0 / 92)$, the normed index of the fitness $(\mathrm{NFI}=0 / 98)$ and the adaptive fitness index $(\mathrm{CFI}=0 / 99)$ that indicate that the models index is suitable. The obtained results indicate that considering the path coefficient $(0 / 90)$ it is certain that the effect of brand equity on the brand trust in Iran insurance company in Hamedan is positive and Ho hypothesis is rejected and its opposite hypothesis is confirmed. 
The value of t-statistics between the variables of the brand equity and brand trust is equal to $9 / 34$ that is more than $1 / 96$ and it indicates that the relationship between the brand equity and brand trust in confidence level of $95 \%$ is significant. Thus it can be said that $t-$ statistics rate of the third hypothesis (9/34) is out of the range of $-1 / 96$ and $+1 / 96$ there for the third hypothesis is confirmed. In other words it can be said that the brand equity can justify $90 \%$ of changes in the brand trust. Therefore the first hypothesis is confirmed. In other words it can be said that the brand equity has a positive and significant effect on the brand trust in Iran insurance company in Hamedan city. Therefore any evidence for rejection of the third hypothesis was not observed and this hypothesis cannot be rejected.

The obtained results of the fourth hypothesis analysis indicate that the brand attractiveness has a positive and significant effect on the repurchase attractiveness in Iran insurance to the results of model calculations, the value of chi- square goodness of fit index of 23/10 $x^{2}$ with degree of freedom 13 and significance level of $p=0 / 041$ was obtained.

Other attributes of model fitness include the root index of mean error of approximate square $($ RMSEA $=0 / 079)$, the goodness of fit index $(\mathrm{GFI}=0 / 92)$

The modified goodness of it index (AGFI $=0 / 98)$, the normed index of the fitness $(\mathrm{NFI}=0 / 97)$ and adaptive fitness index (CFI = $0 / 98$ ) that indicate the models fitness is suitable. The obtained results indicate that considering the path coefficient $(0 / 90)$ it is certain that the effect of brand attractiveness on the repurchase intention in Iran insurance company is positive and Ho hypothesis is rejected and its opposite hypothesis (H1) is confirmed. The value of $t-$ statistic between the variables of brand attractiveness and repurchase intention in the confidence level of \%95 is significant.

Thus it can be said that considering this fact that the $\mathrm{t}$ - statistics rate of the fourth hypothesis (6/96) is out of the range of $-1 / 96$ and $+1 / 96$. there four the fourth hypothesis is confirmed. In other words it can said that the brand attractiveness can justify $90 \%$ of change in the repurchase intention.
Therefore the fourth hypothesis is confirmed. In brand attractiveness has a positive and significant effect on the repurchase intention in Iran insurance company in Hamedan city. There four, any evidence for rejection of the fourth hypothesis not observed and this hypothesis cannot be rejected.

The obtained results of the fifth hypothesis analysis indicated that the brand trust has a positive and significant effect on the repurchase intention in Iran insurance company in Hamedan city. According to the results of model calculations the value of chi - square goodness of fit index of $13 / 37 x^{2}$ with degree of freedom 8 and significance level of $\mathrm{p}=$ 0/069 was obtained other attributes of model fitness include the root index of the mean error of approximate squares (RMSEA $=0 / 073)$, the goodness of fit index $(\mathrm{GFI}=0 / 79)$, the modified goodness of fit index $(\mathrm{AGFI}=0 / 91)$, the normed index of the fitness $(\mathrm{NFI}=0 / 98)$ and adaptive fitness index $(\mathrm{GFI}=0 / 98)$ that indicate that models fitness is suitable. The obtained results indicate that considering the path coefficient $(0 / 80)$ it is certain that the effect of brand trust on the repurchase intention in Iran insurance company is positive and Ho is rejected and its opposite hypothesis (H1) is confirmed. the value of $\mathrm{t}$ - statistics between the variables of brand trust and repurchase intention is equal to $5 / 17$ that is more than $1 / 96$ and it indicate that the relationship between the brand trust and repurchase intention in confidence level of $95 \%$ is significant.thus it can be said that considering this fact that the $\mathrm{t}-$ statistics rate of the fifth hypothesis $(5 / 17)$ is out of the range of $-1 / 96$ to $+1 / 96$. Therefore the fifth hypothesis is confirmed In other words it can be said that the brand trust can justify $80 \%$ of changes in the repurchase intention.

There four, the fifth hypothesis is confirmed. In other words it can be said that the brand trust has a positive and significant effect on the repurchase intention.

In Iran insurance company in Hamedan city. Therefore, any evidence for rejection of the fifth hypothesis was not observed and this hypothesis cannot be rejected the obtained results of the sixth hypothesis analysis indicated that the brand attractiveness has a positive and significant effect on the brand trust in Iran insurance company in Hamedan city. 
According to the results of model calculations the value of chi - square goodness of fit index of $2 / 31 x^{2}$ with degree of freedom 4 and significance level of $p=0 / 68$ was obtained. other attributes of model fitness include the root index of the mean error of approximate squares (RMSEA $=0 / 0$ ), the goodness of fit index $(\mathrm{GFI}=0 / 99)$, the modified normed index of the fitness (GFI = 0/99) that indicate that models fitness is suitable.

The obtained results indicate that considering the path coefficient $(0 / 90)$ it is certain that the effect of brand attractiveness on the brand trust in Iran insurance company is positive and Ho is rejected, and its opposite hypothesis ( $\mathrm{H}$ 1) is confirmed the value of $t-$ statistics between the variables of brand attractiveness and brand trust is equal to $7 / 63$ that is more than $1 / 96$, it indicates that the relationship between the brand attractiveness and the brand trust in confidence level of $95 \%$ is significant.

Thus it can be said that considering this fact that $\mathrm{t}$ - statistics rate of the sixth hypothesis (7/63) is out of the range of $-1 / 96$ to $+1 / 96$, therefore the sixth hypothesis is confirmed. In other words it can be said that the brand attractiveness can justify $90 \%$ of the changes in the brand trust. therefore the sixth hypothesis is confirmed. In other words it can be said that the brand attractiveness has a positive and significant effect on the brand trust in Iran insurance company in Hamedan city. There four any evidence for rejection of the sixth hypothesis was not observed and this hypothesis cannot be rejected.

\section{References}

Aaker, D. A. (1991). Managing Brand Equity. New York: The Free Press.

Aaker, David A., \& Joachimsthaler, Erich. (2000). Brand Leadership: The Next Level of the Brand Revolution: Free Press.

Alexandris, K., Dimitriadis, N., \& Markata, D. (2002). Can perceptions of service quality predict behavioral intentions? An exploratory study in the hotel sector in Greece. Managing Service Quality, Vol. 12, No. 4.
Bamert, T., \& Wehrli, H. P. (2005). Service quality as an important dimension of brand equity in Swiss services industries. Managing Service Quality, 15(2), 132-141.

Baumgarth, Carsten, \& Schmidt, Marco. (2010). How strong is the business-to-business brand in the workforce? An empirically-tested model of internal brand equity in a business-tobusiness setting. Industrial Marketing Management, 39(3), 1250-1260 .

Berry, Leonard L. (2000). Cultivating Service Brand Equity. Academy of Marketing Science, 28(1), 128-137.

Biedenbach, Galina, Bengtsson, Maria, \& Wincent, Joakim. (2011). Brand equity in the professional service context: Analyzing the impact of employee role behavior and customer-employee rapport. Industrial Marketing Management, 40(7), 1093-1102 .

Blankson, Charles, \& Kalafatis, Stavros P . (1999) .Issues and challenges in the positioning of service brands: a review. Journal of Product \& Brand Management, 8(2), 106-118 .

Burmann, Christoph, \& Zeplin, Sabrina. (2005). Building brand commitment: a behavioral approach to internal brand management. Brand Management, 12(4), 279-299.

Burmann, Christoph, Zeplin, Sabrina, \& Riley, Nicola. (2009). Key determinants of internal brand management success: An exploratory empirical analysis. Journal of Brand Management, 16(4), 264-284 .

Davis, J. A (2010). Competitive success: how branding adds value( 1 ed). British Johnwily and sons.

Ercis, A., Unal, S., Candan, F. B. \& Yildirim, H. (2012). "The effect of brand satisfaction, trust andbrand commitment on loyalty and repurchase intentions", Procedia - Social and Behavioral Sciences,58 (12), pp. 1395-1404.

Erdem,T. \& Swait,J.(2004) “Credibility, Brand Consideration and Choice". Journal of Consumer Research Inc. Vol, 31. June,2004. pp. 191-198. 
Etemadifard, M., Kafashpoor, A., \& Zendehdel, A., (2013), The Effect of Brand Communication and Service Quality in the Creation of BrandLoyalty through Brand Trust (Case Study: Samsung's Representatives Company inMashhad City), International Journal of Advanced Studies in Humanities and Social Science, Volume 1, Issue 8, pp: 1067-1077.

Farquhar, P. H. (1989). Managing brand equity. Marketing Research, 1(3), 24-33.

Gwinner, K., \& Bennett, G., (2013), The Impact of Brand Cohesiveness and Sport Identification on Brand Fit in a Sponsorship Context, Journal of Sport Management, 22, pp: 410-426.

Ha, Y. H., John, J., Janda, S. \& Muthaly, S. (2011). "The effects of advertising spending on brandloyalty in services", European Journal of Marketing, 45 (4), pp. 673-691.

Haenlein, Michael \& ,Kaplan, Andreas M. (2004). A Beginner's Guide to Partial Least Squares Analysis. Understanding Statistics, 3(4), 283-297 .

Heidarzadeh, K.., Bigdeli, F., Khanzadeh, M and Javanbakht, A. (2012).Assessing Patients Behavioral Intentions through Service Quality and Perceived Value.J. Basic. Appl. Sci. Res. 2(10)1086-92.

Hong, I.B., Cho, H. (2011). The impact of consumer trust on attitudinal loyalty and purchase intentions inB ${ }^{r} \mathrm{C}$ e-marketplaces: Intermediary trust vs. seller trust. International Journal of Information Management,31, pp: 469- 479.

Hongwei, H., Yan, L., \& Harris, L, (2012), Social identity perspective on brand loyalty, Journal of Business Research, 65, pp: 648-657.

Hsu, H. C., Oh, H. \& Assaf, G. A. (2012). "A customer-based brand equity model for upscale hotels",Journal of Travel Research, 51 (1), pp. 8193.

Hu, H. Cheng, C. C. Chiu, S. 1. and Hong,F.Y. (2011). A Study of CustomerSatisfaction, Customer Loyalty andQuality Attributes in Taiwan's MedicalService Industry, African Journal of Business Management. 5(1), 187195,Available at: http://www.academicjournals. org/AJBM.
Keller, K. L. (2008). Strategic brand management: building, measuring and managing brand equity ( 3 ed.).

Kim, G., Sun, B. H., \& Priluck, R.(2008). Multidimesional customer - based - Brand equity and its consequeecesin midpriced hotels, journal of hospitality \& tourism research, 23(2), 235-254.

Kim, G., Sun, B. J., \& Kim, H. J. (2008). Multidimensional Customer-Based Brand Equity and Its Consequences in Midpriced Hotels. Journal of Hospitality \& Tourism Research, 23(2), 235-254.

Kimpakorn, Narumon, \& Tocquer, Gerard. (2009). Employees' commitment to brands in the service sector: Luxury hotel chains in Thailand. Journal of Brand Management, 16(8), 532-544 .

Kimpakorn, Narumon, \& Tocquer, Gerard. (2010). Service brand equity and employee brand commitment. Journal of Services Marketing, 24(5), 378-388 .

King, Ceridwyn, \& Grace, Debra. (2006). Exploring managers' perspectives of the impact of brand management strategies on employee roles within a service firm. Journal of Services Marketing, 20(6), 369-380 .

King, Ceridwyn, \& Grace, Debra. (2009). Employee Based Brand Equity: A Third Perspective. Services Marketing Quarterly, 30(2), 122-147.

King, Ceridwyn, \& Grace, Debra. (2010). Building and measuring employee-based brand equity. European Journal of Marketing, 44(7/8), 938-971.

Knox, S., \& Walker, D. (2001). Measuring and managing brand loyalty. Journal of Strategic Marketing, 9, 111-128.

Punjaisri, Khanyapuss, \& Wilson, Alan. (2011). Internal branding process: key mechanisms, outcomes and moderating factors. European Journal of Marketing, 45(9/10), 1521-1537 .

Punjaisri, Khanyapuss, Evanschitzky, Heiner, \& Wilson, Alan. (2009). Internal branding: an enabler of employees' brand-supporting behaviours. Journal of Service Management, 20(2), 209-226 .

HASANI-NASAB, Mahmood. Investigation of the effect of the brand equity on the repurchase intention by mediation of the brand attractiveness and brand trust. ECORFAN Journal-Mexico. 2019. 
Punjaisri, Khanyapuss, Wilson, Alan, \& Evanschitzky, Heiner. (2008). Exploring the Influences of Internal Branding on Employees' Brand Promise Delivery: Implications for Strengthening Customer-Brand Relationships. Journal of Relationship Marketing, 7(4), 407424 .

Robertson K.R., Wood R.V.; Evaluating international markets: The importance of information by industry, by country of destination and by type of export transaction"; International Marketing Review, Vol. 17, No. $1,2000$.

Santos-Vijande, Marsa Leticia, del Rي-Lanza, Ana Belén, SuJrez-ءlvarez, Leticia, \& DيazMartun, Ana Marṣa. (2013). The brand management system and service firm competitiveness. Journal of Business Research, 66(2). 148-157.

Schlager, Tobias, Bodderas, Mareike, Maas, Peter, \& Cachelin, Joël Luc. (2011). The influence of the employer brand on employee attitudes relevant for service branding: an empirical investigation. Journal of Services Marketing, 25(7), 497-508 .

Sweeny, J. \& Swait,J.(2008). "The Effects of Brand Credibility on Customer Loyalty ". Journal of Retailing and Consumer Services.vol,15. No, 8. pp.179-193.

Wallace, Elaine, de Chernatony, Leslie, \& Buil, Isabel. (2013). Building bank brands: How leadership behavior influences employee commitment. Journal of Business Research, 66(2), 165-171.

Washburn,J.H,Till,B.D,Priluck,R(2004)

Brand alliance and customer - based customerbased",psychology \& marketing,21(7),487-508.

Zeithaml, V., \& Bitner, M. (1996). Services Marketing: McGraw-Hill

Doayi - H, kazemi.M and Hosseini Robat.s,(2011).The analysis of the customers perception effect of marketing on the brand (study case: Razavi food products), modern marketing research $104-93$ (2).

Salari, the customers interests and cost, tadbir magazine, 2003, No 150, 49 - 57.
Sobhani. M. I and osmani ember (2012), The study on the relationship between brand awareness and consumer loyalty.

Zohreh Hejazi, Elahe Bazargan. Abass (2009), he methods of behavioral sciences, Tehran, Agah publications.

Sekaran, oma, 2011, The methods of the study of the management, the translation of the Mohammad Saebi and Mohammad Shirazi, Tehran, the eighth edition, the publication of the president governmental management training department.

Soltani Mehdi, Mohammedi Esfandiar, pour Ashraf, Yasanolah and Sayehmiri, Kourosh (2013), The investigation of the effective factors in the consumers attitude of the brand development, Business management period 5, No. 1 - pp $85-104$.

Samadi Mansour, Haji pour, Bahman Dehghan, Meysam (2009), The investigation of the brand dimensions on the customers repurchase intention of Refah chain shop in Tehran city. Andishehye modiriat magazine, third year, the second number $\mathrm{pp}-149-165$.

Azizi. Shahriai, Jamali - Shahram Sanayi Iman (2012), Presentation the effective factors on the staff operation about the brand in banking industry (case study, keshavarzi bank) Business management, period 4, No 11. pp 89- 104. 